Vol 12, Issue 10, 2019

\title{
BIOLOGICAL SYNTHESIS OF KERATIN NANOPARTICLES FROM DOVE FEATHER (COLUMBA LIVIA) AND ITS APPLICATIONS
}

\author{
NANTHAVANAN P, KANDASAMY ARUNGANDHI*, SUNMATHI D, NIRANJANA J
}

Department of Biotechnology, Dr. N.G.P. Arts and Science College, Coimbatore, Tamil Nadu, India. Email: arungandhicbe@gmail.com Received: 26 June 2019, Revised and Accepted: 08 August 2019

ABSTRACT

Objectives: The aim of the present study was to synthesize keratin nanoparticles from dove feathers.

Methods: Crude keratin was extracted by chemical method. The protein content was estimated by Lowry's method and it was found to be 0.18 mg/ml. The keratin nanoparticles were obtained using glutaraldehyde as cross-linking agent.

Results: A single peak maximum at $270 \mathrm{~nm}$ corresponds to the surface plasmon resonance of keratin nanoparticles was observed in the ultravioletvisible spectrum. The size of keratin nanoparticles was $78 \mathrm{~nm}$. The crystalline size of keratin nanoparticles was $79.6 \mathrm{~nm}$ and it was obtained by X-ray diffraction. The antibacterial activity of crude keratin and keratin nanoparticles was determined which revealed that keratin nanoparticles showed higher zone of inhibition than crude keratin protein against Staphylococcus aureus and Salmonella typhi. Keratin nanoparticles showed higher antioxidant activity than crude keratin.

Conclusion: Biological synthesis of nanoparticles has many advantages such as ecofriendly and low cost and can be synthesized in large scale. The keratin nanoparticles can be applied in wound dressing, biosorbent, and cosmetics.

Keywords: Dove feathers, Keratin nanoparticles, X-ray diffraction, Scanning electron microscopy, Antibacterial activity, Antioxidant activity.

(C) 2019 The Authors. Published by Innovare Academic Sciences Pvt Ltd. This is an open access article under the CC BY license (http://creativecommons. org/licenses/by/4. 0/) DOI: http://dx.doi.org/10.22159/ajpcr.2019.v12i10.34572

\section{INTRODUCTION}

Keratin is a fibrous structural protein. It is the key structural material making up feathers, hair, horns, claws, hooves, and the outer layer of human skin [1]. The earliest documented use of keratins for medicinal applications comes from a Chinese herbalist named Zhen in the $16^{\text {th }}$ century [2]. Keratin proteins have several functions such as cytoarchitecture, proliferation and growth, apoptosis, and organelle transport [3,4]. It also protects epithelial cells from damage of stress [5].

Bird's feather contains $90 \%$ keratin protein among their total mass. The worldwide annual feather offal amounts to about $8 \times 10^{5}$ tonnes [6]. India has a large livestock population, in which the annual production of goatskin is $82 \%$, sheepskin is $30 \%$, cattle hides are $23 \%$, and buffalo hides are 28 million among which the world production of bovine and ovine skins was 1192 million pieces during 2000. It is revealed that the quantity of keratins in the form of hairs, feathers, horns, and hoofs is wasted every year [7]. Keratin fibers extracted from chicken feathers are ecofriendly, non-abrasive, biodegradable, insoluble in organic solvents and having good mechanical properties, hydrophobic behavior, low density, and finally cheap [8].

Recently, nanoparticles have attracted the interest of many researchers due to their high surface area, low diffusion resistance, and more active sites [9]. Considering the advantages of nanoparticles and keratin biosorbents, keratin nanoparticles were synthesized in this study.

\section{METHODS}

\section{Sample collection}

The feather samples of dove (Columba livia) were collected from pet shops of Kilakarai locality, Ramanathapuram district, Tamil Nadu. Healthy feathers which appeared in the colors of white, half white, brown, and black were used for the experiment. Collected feathers were brought to the laboratory and washed with detergent and then they were chopped into small pieces and rinsed with distilled water followed by $70 \%$ ethanol and airdried.

\section{Extraction of crude keratin protein}

Dried feathers were dissolved in $5 \%$ of sodium hydroxide solution kept in shaker (Remi) at $70 \mathrm{rpm}$ for $4 \mathrm{~h}$ of incubation. This mixture was then filtered using Whatman No. 1 filter paper. This crude extract was deepfrozen and lyophilized in Lyophilizer (Remi) at $-40^{\circ} \mathrm{C}$, from which the powder form of crude keratin protein was obtained and stored at $4^{\circ} \mathrm{C}$.

\section{Estimation of protein}

Protein was estimated by the method of Lowry's et al. [10].

\section{Synthesis of keratin nanoparticles}

Crude keratin powder $100 \mathrm{mg}$ was diluted by $2 \mathrm{ml}$ of deionized water and was then mixed with $8 \mathrm{ml}$ of absolute alcohol. To this, $1 \mu \mathrm{l}$ of $8 \%$ glutaraldehyde was added. This mixture was stirred using magnetic stirrer at $40 \mathrm{rpm}$ for $24 \mathrm{~h}$. After that, stirred content was centrifuged by cooling centrifuge (Remi) at 10,000 rpm for $20 \mathrm{~min}$. The supernatant was discarded and the pellet was collected and lyophilization process was performed to obtain keratin nanoparticles [11].

\section{Characterization of keratin nanoparticles}

The ultraviolet (UV)-visible absorption spectra of the keratin nanoparticles were recorded using UV-visible spectrophotometer (Cary 8454, Agilent, Singapore) operating in the UV to near-infrared (IR) (200-800 nm) spectral region. The surface properties and purity of keratin nanoparticles were examined by scanning electron microscopy (SEM)-energy-dispersive X-ray (EDX) (JSM 6360 JEOL, Japan) analysis. The particle size distribution was determined by dynamic light scattering (DLS) technique using a sub-micrometer particle size analyzer (Nanophox; Sympatec, Germany) with $10 \mathrm{~mW}$ intensity of $\mathrm{He}-\mathrm{Ne}$ laser as a light source at a wavelength of $632 \mathrm{~nm}$. The SEM was connected to EDX analyzer and the synthesized keratin nanoparticles were monitored for identifying their elemental composition. The X-ray 
diffraction (XRD) technique was used to determine the structural nature and phase of nanoparticles. Fourier transmission IR (FTIR) spectroscopy involves absorption of electromagnetic radiation in the IR region of the spectra, which resulted in changes in the vibrational energy of molecule.

Antibacterial activity of crude keratin protein and keratin nanoparticles

Antibacterial activity was tested by agar well diffusion method using Mueller-Hinton agar. Test bacterial strains used in this study were Salmonella typhi and Staphylococcus aureus. Overnight culture of S. typhi and S. aureus was inoculated into Mueller-Hinton agar using sterile cotton swab. About $5 \mathrm{~mm}$ well was made using sterile cork borer. Crude keratin protein and keratin nanoparticles of various concentrations such as 20,40 , and $100(\mu \mathrm{g} / \mathrm{ml})$ were added into the wells using micropipette; each well was loaded with $40 \mu$ l of sample. It was incubated for $24 \mathrm{~h}$ at $37^{\circ} \mathrm{C}$ and the zone of inhibitions was observed.

Antioxidant assay of crude keratin protein and keratin nanoparticles

In this assay, diphenylpicrylhydrazyl (DPPH) was used as the standard. Working standard of keratin protein and keratin nanoparticles was $0.1 \mathrm{~g} / \mathrm{ml}$. From this series of $0.1,0.2,0.3,0.4$, and $0.5 \mathrm{ml}$ was added in test tubes and $3 \mathrm{ml}$ of DPPH taken were added to all test tubes including the blank, $3 \mathrm{ml}$ of ascorbic acid was added and all the tubes were incubated in room temperature for $30 \mathrm{~min}$. Optical density (OD) reading was observed in UV-visible spectrophotometer at $570 \mathrm{~nm}$. Percentage of free radical property of nanoparticles was measured using the following formula:

$$
\% \text { RSA }=\frac{\text { Abs control }- \text { Abs sample }}{\text { Abs control }} \times 100
$$

Where, RSA is the radical scavenging activity, Abs control is the absorbance of DPPH radical + ascorbic acids, and Abs sample is the absorbance of DPPH radical + keratin nanoparticles.

\section{RESULTS AND DISCUSSION}

\section{Extraction of crude keratin}

Dried feathers were soaked in 5\% of sodium hydroxide solution and kept in shaker (Remi) at $70 \mathrm{rpm}$ for $4 \mathrm{~h}$. This mixture was then filtered using Whatman No. 1 filter paper. This crude extract was deep-frozen and lyophilized in Lyophilizer (Remi) at $-40^{\circ} \mathrm{C} .420 \mathrm{mg}$ of crude keratin powder was obtained and stored at $4^{\circ} \mathrm{C}$ (Fig. 1).

\section{Estimation of protein by Lowry's method}

By plotting standard graph, the concentration of test keratin was found to be $0.18 \mathrm{mg} / \mathrm{ml}$ (Table 1 and Fig. 2). Similar results were reported by Deivasigamani and Alagappan [11] on keratinase production from soluble feather keratin. The amount of $1.44 \mathrm{mg} / \mathrm{ml}$ protein was obtained using the same method. Earlier research by:

Synthesis of keratin nanoparticles

Crude keratin powder $100 \mathrm{mg}$ was diluted by $2 \mathrm{ml}$ of deionized water and then mixed with $8 \mathrm{ml}$ of absolute alcohol, to this $1 \mu \mathrm{l}$ of $8 \%$ glutaraldehyde was added. This mixture was stirred by magnetic stirrer at $40 \mathrm{rpm}$ for $24 \mathrm{~h}$. After that, stirred content was centrifuged by cooling centrifuge (Remi) at 10,000 rpm for $20 \mathrm{~min}$. Supernatant was discarded and pellet was lyophilized. $50 \mathrm{mg}$ of keratin nanoparticles were obtained (Fig. 3).

\section{Characterization of keratin nanoparticles \\ UV-visible spectrophotometer}

The reduction of protein ions formation was confirmed by UV-visible spectrophotometric analysis. The UV-visible spectrum for keratin nanoparticles was obtained by exposing the sample to the UV light from a light source.

A single peak maximum at $270 \mathrm{~nm}$ corresponds to the surface Plasmon resonance of keratin nanoparticles was observed in the UV-visible spectrum. The gradual increase in OD value of reaction mixture indicates the aggregation of keratin nanoparticles in the solution (Fig. 4).

\section{SEM}

SEM was used to record the photomicrograph images of synthesized keratin nanoparticles. A small volume of keratin nanoparticles suspension was taken for SEM analysis on electron microscope stub.

The stub placed briefly in a drier and then coated with titanium in an ion sputter. The pictures were taken by random scanning of the stub. The morphology of keratin nanoparticle was crystalline shape and aggregated into the larger structure. The SEM micrograph showed the presence of keratin nanoparticles and its polydispersity. The crystalline size of keratin nanoparticles was $79.6 \mathrm{~nm}$ (Fig. 5). Similarly, Meignanalakshmi et al. [12] reported that the size of keratin nanoparticles was $78 \mathrm{~nm}$. Keratin nanoparticles complexes are spherical in nature, particle size was found to be $100-160 \mathrm{~nm}$ [13].

Table 1: Estimation of protein by Lowry's method

\begin{tabular}{llll}
\hline S. No. & Sample name & $\begin{array}{l}\text { Volume of } \\
\text { sample }(\mathbf{m l})\end{array}$ & $\begin{array}{l}\text { Optical density } \\
\text { at } \mathbf{6 6 0} \mathbf{~ n m}\end{array}$ \\
\hline 1. & Blank & - & 0.00 \\
2. & S1 & 0.2 & 0.42 \\
3. & S2 & 0.4 & 0.63 \\
4. & S3 & 0.6 & 0.81 \\
5. & S4 & 0.8 & 0.92 \\
6. & S5 & 1.0 & 1.13 \\
7. & T1 & 0.2 & 0.23 \\
8. & T2 & 0.4 & 0.40 \\
\hline
\end{tabular}
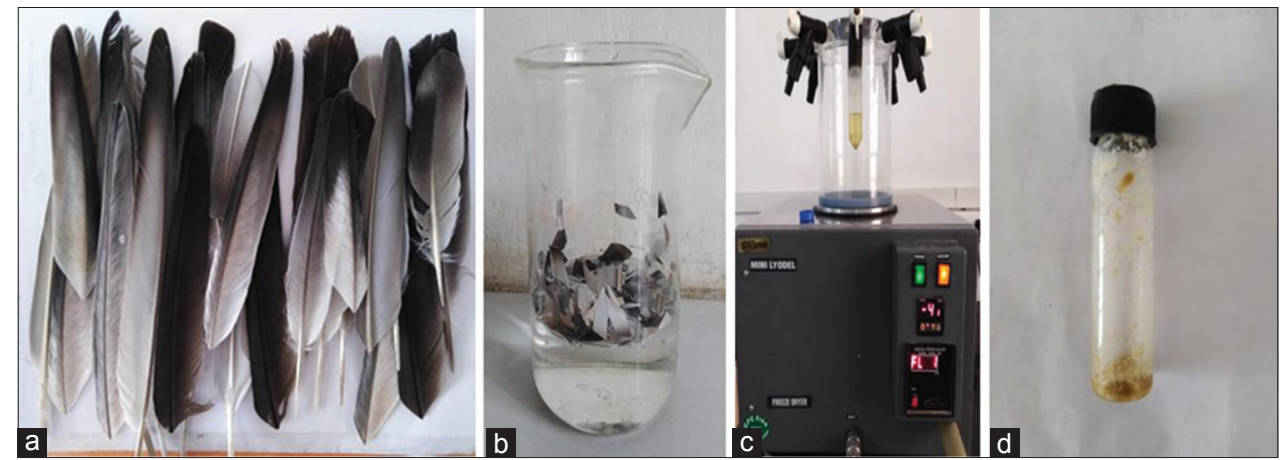

Fig. 1: Extraction of crude keratin (a) Collection of dove feathers. (b) Dove feathers dissolved in sodium hydroxide solution. (c) Obtained extract was lyophilized. (d) Crude keratin powder was collected 


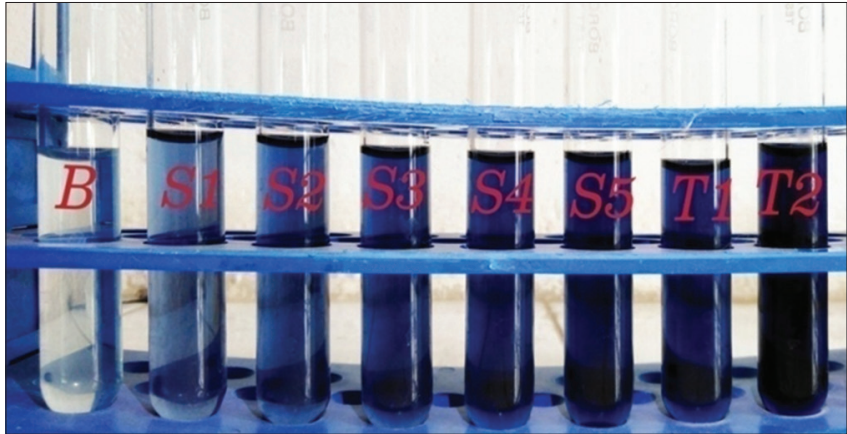

Fig. 2: Protein estimation of Lowry's method

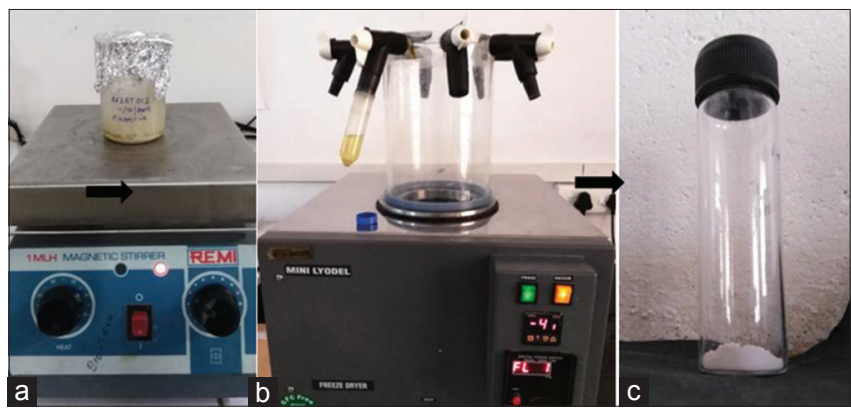

Fig. 3: Synthesis of keratin nanoparticles (a) Crude keratin with glutaraldehyde was kept in magnetic stirrer. (b) Obtained extract was lyophilized. (c) Keratin nanoparticles were obtained

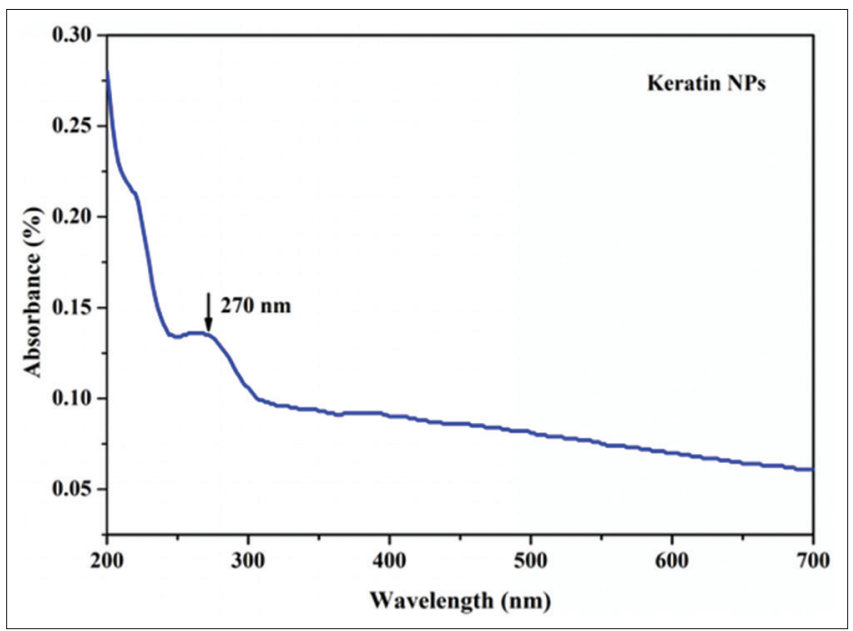

Fig. 4: Absorbance of keratin nanoparticles

$D L S$

The prostate-specific antigen results showed that the synthesized keratin nanoparticles possessed an average size of about $11.26 \mathrm{~nm}$ (Fig. 6). Likewise, keratin nanoparticles from controlled gastric mucoadhesion with an average size ranged from 200 to $400 \mathrm{~nm}$, which was consistent with the result of particle size detection [15]. Keratin silver nanoparticles are in the range of 50-100 nm with an average size of $71.8 \mathrm{~nm}$ and keratin gold nanoparticles are in the range of $8-30 \mathrm{~nm}$ with mean size of $14.0 \mathrm{~nm}$ [13].

$E D X$

Analysis through EDX spectrometer confirmed the presence of elements of keratin nanoparticles. The vertical axis displays the number of X-ray counts with the horizontal axis displayed energy in keV. Identification lines for the major emission energies for keratin were displayed and corresponded with peaks in the spectrum, thus giving confidence that keratin has been correctly identified.

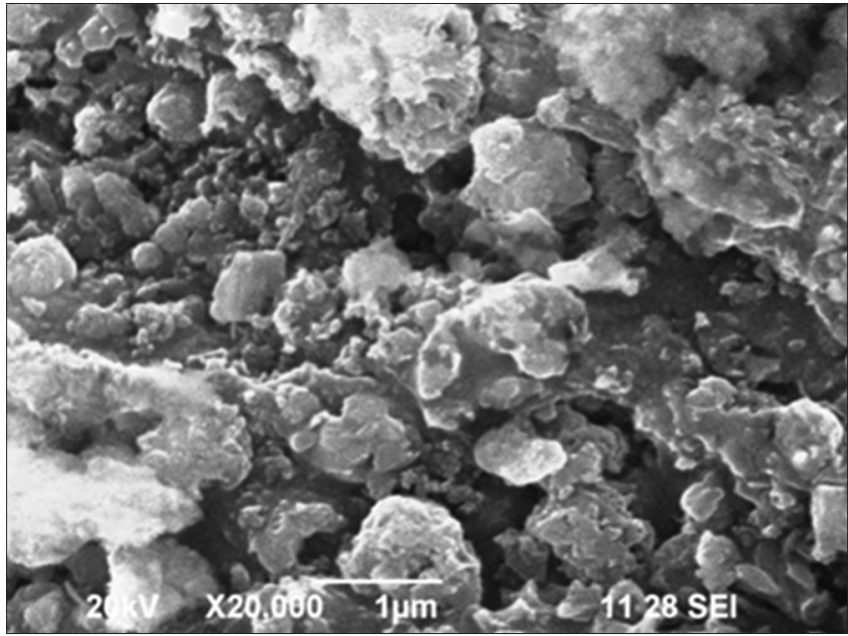

Fig. 5: Scanning electron microscopy image of keratin nanoparticle

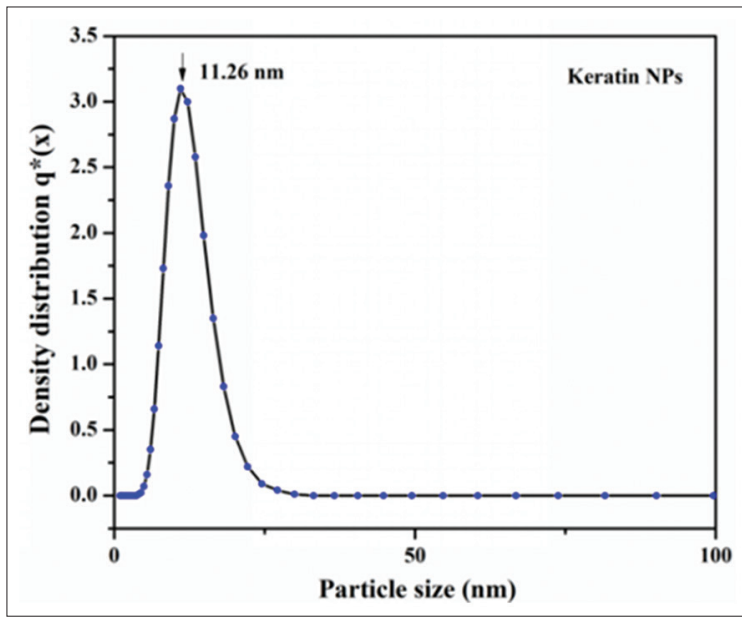

Fig. 6: Dynamic light scattering of keratin nanoparticles

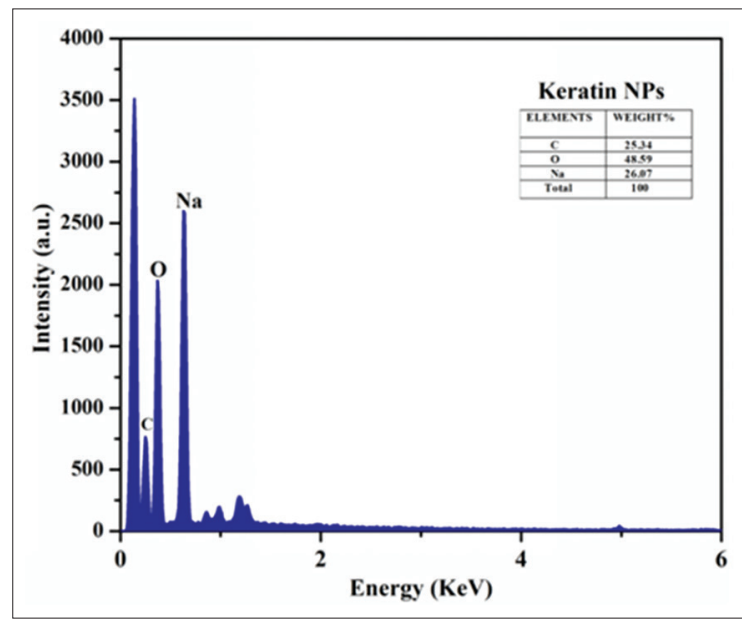

Fig. 7: Energy dispersive X-Ray analysis results of keratin nanoparticles

The peaks around $0.3 \mathrm{keV}, 0.4 \mathrm{keV}$, and $0.7 \mathrm{keV}$ correspond to the binding energy of $\mathrm{C}, \mathrm{O}$, and $\mathrm{Na}$, respectively (Fig. 7). The peaks around $0.5 \mathrm{keV}, 1.5 \mathrm{keV}, 2 \mathrm{keV}$, and $5 \mathrm{keV}$ for the samples of keratin nanoparticles correspond to the binding energy of $\mathrm{C}, \mathrm{O}, \mathrm{Na}$, and $\mathrm{Ag}$, respectively [13]. 
XRD

The XRD diffractogram obtained to assess the physical characterization of keratin nanoparticles in shown in Fig. 8; different peaks at $\theta=16,31,37$, and 45 indicated that the nanoparticles had a mixed amorphous crystalline structure. Selvaraj et al [14]. (2018) described that the nanoparticles had a mixed amorphous-crystalline structure on diffraction peaks at $2 \theta=5,22$, and 43 (Fig. 8). Diffractogram of CEL+KER+Ag+NPs composite exhibits three major peaks at $2 \theta=27.94,32.35$, and 46.37 which are characteristics of the peaks of keratin-derived silver nanoparticles [16]

\section{FTIR}

For the extracted keratin nanoparticles, band at $1653 \mathrm{~cm}^{-1}$ is assigned to the amide I of protein, respectively, and the band observed at $1119 \mathrm{~cm}^{-1}$ can be assigned to the $\mathrm{C}-\mathrm{N}$ stretching vibrations of the amines (Fig. 9). Earlier research showed that the FTIR spectra of the extracted keratin showed 400-4000 $\mathrm{cm}^{-1}$ [16]. It demonstrated the stretching of ether group on $1035 \mathrm{~cm}^{-1}$. The vibration band on $866 \mathrm{~cm}^{-1}$ ascribed to alcohol (Fig. 10). The characteristic frequency of hydrogen-bonded N-H has been observed at $3142 \mathrm{~cm}^{-1}$. The Ag microparticle showed peak on $2467 \mathrm{~cm}^{-1}$. The extracted keratin forms two bands $1653 \mathrm{~cm}^{-1}$ and 1583 $\mathrm{cm}^{-1}$ were assigned to the amide I and II bands of protein [17].

Antibacterial activity of crude keratin protein and keratin nanoparticles

Antibacterial activity of keratin nanoparticles and crude keratin was tested against $S$. aureus and $S$. typhi. The diameter of the zone of inhibition for keratin nanoparticles against $S$. aureus and $S$. typhi was

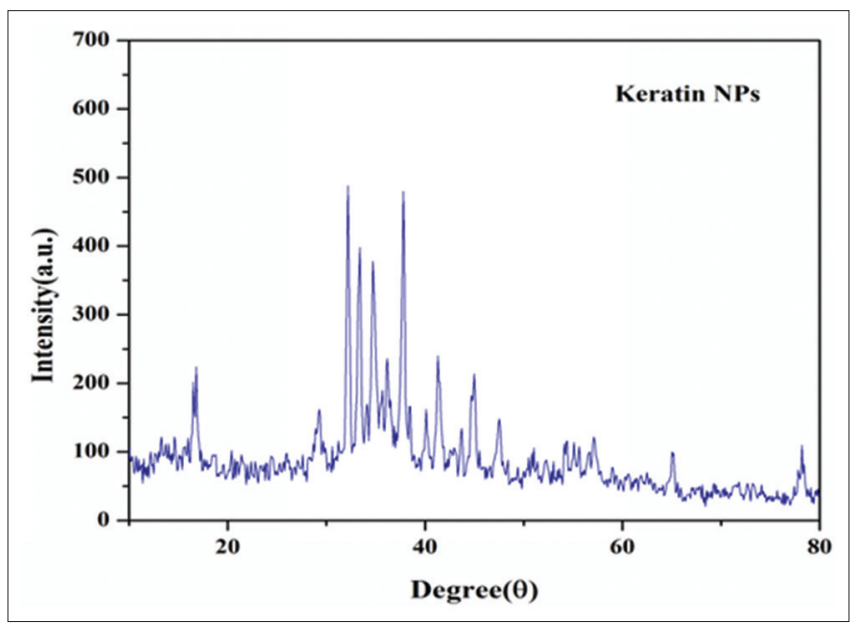

Fig. 8: X-ray diffraction patterns of keratin nanoparticles

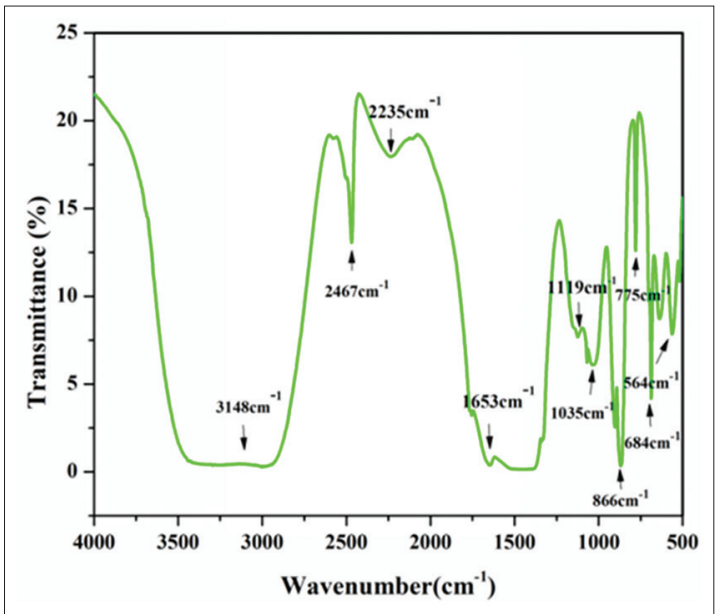

Fig. 9: Fourier transmission infrared result of keratin nanoparticle
$24 \mathrm{~mm}$ and $28 \mathrm{~mm}$, respectively. The diameter of the zone of inhibition for crude keratin against $S$. aureus and S. typhi was $23 \mathrm{~mm}$ and $27 \mathrm{~mm}$, respectively (Table 2).

The zone of inhibition of keratin was in the diameter of $9.5 \mathrm{~mm}$ against S. aureus and $11 \mathrm{~mm}$ against Escherichia coli 9 . Human hair keratin exhibited the antibacterial activity against $E$. coli $(3.2 \mathrm{~cm}$ in diameter) and Klebsiella pneumonia (4.4 cm in diameter) [13].

Antioxidant activity of crude keratin protein and keratin nanoparticles

DPPH is a stable free radical that showed maximum absorbance at $517 \mathrm{~nm}$. The DPPH free radical scavenging activity was investigated at various concentrations such as $0.1,0.2,0.3,0.4$, and $0.5 \mu \mathrm{g} / \mathrm{ml}$. The maximum

Table 2: Antibacterial activity of crude keratin protein and keratin nanoparticles

\begin{tabular}{lll}
\hline Sample & Zone of inhibition \\
\cline { 2 - 3 } & Staphylococcus aureus & Salmonella typhi \\
\hline Keratin protein & $23 \mathrm{~mm}$ & $27 \mathrm{~mm}$ \\
Keratin nanoparticles & $24 \mathrm{~mm}$ & $28 \mathrm{~mm}$ \\
Positive control & $25 \mathrm{~mm}$ & $29 \mathrm{~mm}$ \\
Negative control & - & - \\
\hline
\end{tabular}

Table 3: Antioxidant activity of crude keratin protein and keratin nanoparticles

\begin{tabular}{lll}
\hline Sample & $\begin{array}{l}\text { Concentration } \\
(\boldsymbol{\mu g} / \mathbf{m l})\end{array}$ & $\begin{array}{l}\text { Free radical } \\
\text { scavenging (\%) }\end{array}$ \\
\hline Standard (ascorbic acid) & 0.1 & 81.23 \\
Keratin protein & 0.1 & 56.33 \\
& 0.2 & 61.11 \\
& 0.3 & 76.11 \\
Keratin nanoparticles & 0.4 & 81.66 \\
& 0.5 & 85.55 \\
& 0.1 & 72.22 \\
& 0.2 & 77.22 \\
& 0.3 & 81.66 \\
& 0.4 & 91.66 \\
& 0.5 & 94.44 \\
\hline
\end{tabular}

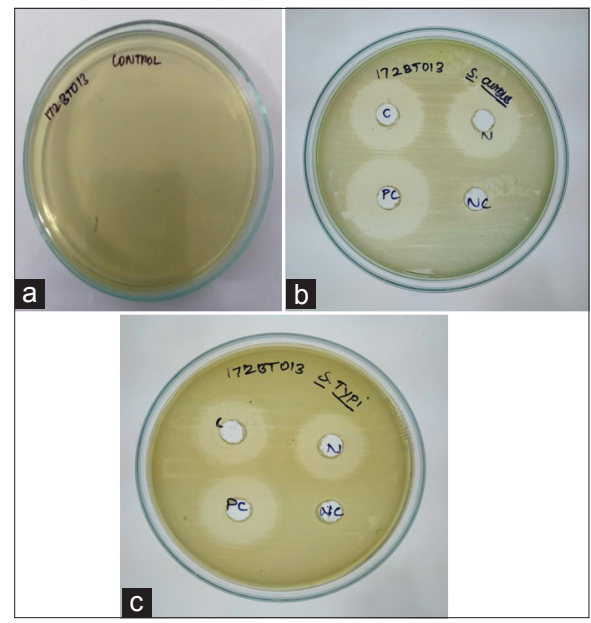

Fig. 10: Antibacterial activity of keratin protein and keratin nanoparticles (a) Control. (b) Keratin protein and keratin nanoparticles against Staphylococcus aureus. (c) Keratin protein and keratin nanoparticles against Salmonella typhi. C: Crude keratin, N: Keratin nanoparticles, PC: Positive control (streptomycin $0.1 \mathrm{~g} / \mathrm{ml}$ ), NC: Negative control (sterile distilled water) 
percentage of radical scavenging activity of keratin protein by ascorbic acid was $85.55 \%$ and at $0.5 \mu \mathrm{g} / \mathrm{ml}$ (Table 3). The percentage of antioxidant activity increased with respect to the concentration of keratin protein and keratin nanoparticles. The percentage of free radical scavenging activity for keratin nanoparticles is $94.44 \%$ at $0.5 \mu \mathrm{g} / \mathrm{ml}$ which is higher than the antioxidant activity of keratin protein. Keratin nanoparticles obtained from chicken feather wastes showed $77.9 \%$ at $350 \mu \mathrm{g} / \mathrm{ml}$ [13].

\section{CONCLUSION}

Utilization of feathers may lead to reduction in waste management. The management of keratin-based waste biomass by reconversion into commercially used product will not solely save the ecosystem from great amount of sludge, however, will economically improve the industries. The synthesized keratin nanoparticles can be applied in wound dressing, biosorbent, and cosmetics.

\section{ACKNOWLEDGMENTS}

The authors thank the management, principal, and deans of Dr. N.G.P. Arts and Science College, Coimbatore, for providing the facilities to pursue the research work (Communication No: DrNGPASC 20192020 BS004). The authors are also thankful to the Department of Biotechnology star scheme and DST-FIST scheme.

\section{AUTHORS' CONTRIBUTIONS}

All authors have equally contributed to the research study.

\section{CONFLICTS OF INTEREST}

None.

\section{REFERENCES}

1. Arun G, Kumar P, Yunus RB, Kamarudin NB. Extraction of Keratin Protein from Chicken feather. Chemeca Engineering a Better World: Sydney Hilton Hotel, NSW, Australia, Conference paper; 2011. p. 18-21.

2. Zhen LS. Ben Cao Gang Mu. Changchun, Jilin, China: The Time Literature and Art Press; 2005.

3. Toivola DM, Tao GZ, Habtezion A, Liao J, Omary MB. Cellular integrity plus: Organelle-related and protein-targeting functions of intermediate filaments. Trends Cell Biol 2005;15:608-17.

4. Kim S, Coulombe PA. Intermediate filament scaffolds fulfill mechanical, organizational, and signaling functions in the cytoplasm. Genes Dev 2007;21:1581-97.

5. Korniłłowicz-Kowalska T, Bohacz J. Biodegradation of keratin waste: Theory and practical aspects. Waste Manag 2011;31:1689-701.

6. Grazziotin A, Pimentel FA, De Jong EV, Brandelli A. Nutritional improvement of feather protein by treatment with microbial keratinase. Anim Feed Sci Technol 2006;1261:135-44.

7. Kumawat TK, Sharma A, Sharma V, Chandra S. Keratin Waste: The Biodegradable Polymers. Doi: 10.5772/intechopen.79502.

8. Kumaran P, Gupta A, Sharma S. Synthesis of wound-healing keratin hydrogels using chicken feathers proteins and its properties. Int J Pharm Pharm Sci 2007;9:171-8

9. Lowry OH, Rosebrough NJ, Farr AL, Randall RJ. Protein measurement with the folin phenol reagent. J Biol Chem 1951;193:265-75.

10. Acda MN. Waste chicken feathers as reinforcement in cement bonded composites. Philipp J Sci 2011;139:161-6.

11. Deivasigamani B, Alagappan KM. Industrial application of keratinase and soluble proteins from feather keratins. J Environ Biol 2008;29:933-6.

12. Meignanalakshmi S, Legadevi R, Banu NA, Gayathri V, PalanisammyA. A study on anti bacterial activity of keratin nanoparticles from chicken feather waste against Staphylococcus aureus (Bovine Mastitis Bacteria) and its anti oxidant activity. Eur J Biotechnol Biosci 2015;3:1-5.

13. Shanmugasundaram OL, Ramkumar M. Characterization and study of physical properties and antibacterial activities of human hair keratin silver nanoparticles and keratin gold nanoparticles coated cotton gauze fabric. J Ind Text 2018;47:798-814.

14. Kunjiappan S, Panneerselvam T, Prasad P, Sukumaran S, Somasundaram B, Sankaranarayanan $\mathrm{M}$, et al. Design, graph theoretical analysis and in silico modeling of Dunaliella bardawil biomass encapsulated keratin nanoparticles: A scaffold for effective glucose utilization. Biomed Mater 2018;13:045012.

15. Cheng Z, Chen X, Zhai D, Gao F, Guo T, Li W, et al. Development of keratin nanoparticles for controlled gastric mucoadhesion and drug release. J Nanobiotechnology 2018;16:24.

16. Tran CD, Prosenc F, Franko M, Benzi G. One-pot synthesis of biocompatible silver nanoparticle composites from cellulose and keratin: Characterization and antimicrobial activity. ACS Appl Mater Interfaces 2016;8:34791-801.

17. Madapally VD, Pandimadevi M. Fabrication of nanofibres by electro spinning using keratin from waste chicken feathers, PVA and AGNPS. Int J Pharm Pharm Sci 2019;11:78-84. 